
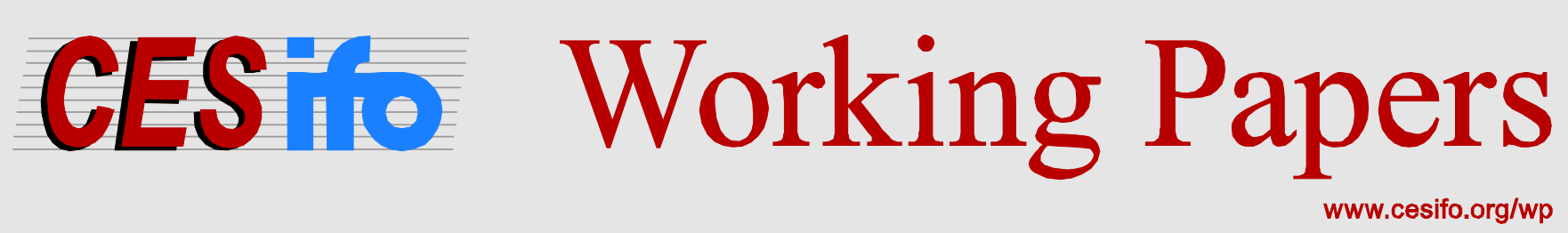

\title{
Estimating Labour Supply Elasticities Based on Cross-Country Micro Data: A Bridge Between Micro and Macro Estimates?
}

\author{
Markus Jäntti \\ Jukka Pirttilä \\ Håkan Selin
}

CESIFO WORKING PAPER NO. 4994

CATEgORY 1: Public FinANCE

SEPTEMBER 2014

An electronic version of the paper may be downloaded

- from the SSRN website:

- from the RePEc website:

- from the CESifo website:

wWw.SSRN.com

www.RePEc.org

www.CESifo-group.org/wp 


\title{
Estimating Labour Supply Elasticities Based on Cross-Country Micro Data: A Bridge Between Micro and Macro Estimates?
}

\begin{abstract}
We utilise repeated cross sections of micro data from several countries, available from the Luxembourg Income Study, LIS, to estimate labour supply elasticities, both at the intensive and extensive margin. The benefit of the data is that it spans over four decades and includes a large number of tax reform episodes, with tax rate variation arising both from cross-sectional and country-level differences. Using these data, we investigate whether micro and macro estimates differ in a systematic way. The results do not provide clear support to the view that elasticities at the macro level would be higher than corresponding micro elasticities.
\end{abstract}

JEL-Code: E240, H210, J220.

Keywords: labour supply, taxation, cross-country comparisons.

Markus Jäntti

Swedish Institute for Social Research

Stockholm University / Sweden

markus.jantti@sofi.su.se
Jukka Pirttilä

School of Management

University of Tampere / Finland

jukka.pirttila@uta.fi

Håkan Selin

The Institute for Evaluation of Labour

Market and Education Policy

Uppsala Center for Fiscal Studies / Sweden

hakan.selin@ifau.uu.se

September 17, 2014

We are grateful numerous seminar participants at the Conference on the Economics of the Nordic Model (Oslo), CESifo and elsewhere for useful comments. Allan Seuri provided excellent research assistance. Financial support from the Yrjö Jahnsson Foundation and the Finnish Employees’ Foundation is gratefully acknowledged. 


\section{Introduction}

Much of the modern empirical evidence on the impact of taxation on labour supply and taxable income is based on careful examination of how individuals react to tax reforms. This type of micro-data based evidence has been argued to plausibly identify the causal effects of tax changes on taxpayer behaviour. It is summarised by Meghir and Phillips (2010) in their chapter for the authoritative treatment of tax research in the Mirrlees Review. They conclude that while labour market participation decisions can be quite elastic with respect to the take-home pay when working versus when unemployed (the 'extensive margin'), the working hours of those who already work (the 'intensive margin') are typically quite unresponsive to tax rates. While taxable income estimates are typically higher than estimates of working hours responses (for a recent survey, see Saez, Slemrod, and Giertz, 2012), even taxable income responses are typically modest; typical values for taxable income elasticities with respect to the net-of-tax rate (=1-marginal tax rate) are around 0.2-0.5.

However, there is a large discrepancy between some of the macroeconomic work and microeconometric evidence on the employment effects of taxation of labour income. Some macroeconomists suggest, including the provocative paper by Prescott (2004), that tax differences explain virtually all the differences in working hours between the US and Europe. Large elasticities are also needed for conventional macro models to match the empirical fluctuations in aggregate employment over business cycles. Sometimes macro studies are based on simple cross-country comparisons and they do not typically pay attention to endogeneity issues, such as the possibility that if the economy performs badly and unemployment rises, countries need to raise taxes to balance budgets. And they often omit other potential explanatory variables that could affect employment. ${ }^{1}$

But it is not clear either that the micro estimates provide the correct estimates of the long run effects of taxes on labor supply behaviour, for the following reasons. There are now several recent papers that aim to explain why micro and macro estimates differ so significantly. Chetty (2012) provides the first possible solution building on frictions. While micro evidence has paid a lot of attention to carefully estimating the causal effects of specific tax changes, these tax changes are often too small to generate really large society-wide impacts. If there are frictions related to re-optimisation of labour supply and income generation, it may not be worthwile for the individuals to react to small tax changes. Then estimates based on micro evidence can be downwards biased, whereas the tax differences between countries are often so large that, in the long run at least, the economy and the individuals have reacted to those optimally. In Chetty et al. (2011a), the authors demonstrate that if taxation of households creates economy-wide structures, employers are likely to cater for employees' desires by offering compensation packages that suit the majority of the workforce. They also provide evidence from Denmark, where many taxpayers (and in particular in occupations where compensation packages can be tailored

\footnotetext{
${ }^{1}$ Nickell (2003) concludes that when other potential explanations for employment behaviour (such as differences in wage setting frameworks and social security systems) are accounted for, a 10 percent difference in taxes on labour income explains roughly 2 per cent of cross-country variation in employment rates.
} 
well) bunch at income levels where they just avoid paying an increased state-level marginal tax rate. Chetty et al. (2011a) also show how smaller tax changes, which do not affect all tax payers, generate much smaller behavioural elasticities than a single large increase in the marginal tax rate at the country level.

The second explanation is related to indivisible labour and varying responses along the intensive and extensive margin. A key paper in this strand of research is Rogerson and Wallenius (2009), who introduce the extensive margin to an otherwise standard macro model and demonstrate how the presence of fixed costs generates a realistic life-cycle profile or labour supply. While taxation might not matter so much for the hours choice of the working age population, it can have a sizeable impact on the length of the working life, so that at the aggregate level hours become quite responsive to tax changes.

The third explanation, building on Imai and Keane (2004), relies on the way human capital formation interacts with taxation. In a learning-by-doing framework, taxation can have significant long-run consequences, because if it leads to lower working hours in a current period, it also depresses wages in later periods. Therefore the cumulative distortionary effect of taxation, which matters at a macro level, could be much higher than what a typical static micro estimate would suggest.

The differences between micro and macro elasticities can also be linked to the work on social norms and the welfare state of Lindbeck, Nyberg, and Weibull (1999). When individuals suffer from a stigma when living off benefits, and this stigma is decreasing in the share of the population on benefits, it is conceivable that tax increases first reduce little one's work effort, but gradually that has an externality on others via the social norm and in the end the overall, macro, effect is greater than the first measured micro response.

Finally, even if the majority of micro-level labour supply studies would imply fairly small elasticities at the intensive margin, some of the elasticity of taxable income studies, surveyed recently by Saez, Slemrod, and Giertz (2012), find much larger elasticities, especially at the top of the income distribution. However, these elasticities capture for instance income shifting behaviour, and cannot be directly used to predict cross-country differences in employment. ${ }^{2}$

Despite this emerging research, the issue is, however, far from settled. This is reflected in the conclusions by two recent surveys on the topic by leading researchers in the field. Chetty et al. (2012) conclude that

"Based on our reading of the micro evidence, we recommend calibrating macro models to match Hicksian elasticities of 0.3 on the intensive and 0.25 on the extensive margin,"

which would lead to a combined macro elasticity of approximately 0.5 . In contrast, Keane and Rogerson (2012) argue that

"In our view, the literature we have described can credibly support a view that compensated and intertemporal elasticities at the macro level fall in the range of 1 to 2 that is typically

\footnotetext{
${ }^{2}$ Piketty, Saez, and Stantcheva (2011) estimate top income elasticities using macro data.
} 
assumed in macro general equilibrium models."

Since reliable evidence on the impacts of tax changes on working hours is one of the most important knowledge economic policymakers need, there is clearly an urgent need for further research that could help us understand the differences between these recommendations.

The purpose of this paper is to shed new light on this micro-macro controversy by estimating labour supply elasticities using micro-level data from a set of different industrialised countries. Building on a high-quality, harmonised and comparable data from the Luxembourg Income Study (LIS), we employ the repeated cross-section estimation method developed by Blundell, Duncan, and Meghir (1998) to estimate the elasticity of working hours and participation at the micro level, macro level and at an intermediate level where the tax variation arises from both cross-sectional and cross-country sources.

The value-added in the paper is the following. First, the data span over several decades and countries and contain a large number of tax reform episodes, including major tax reforms, which means that there is good scope for reliable estimation. Additionally, tax changes have taken place across the income distribution, not only among top income earners.

Second, we use the same estimator and harmonised data to estimate micro and macro elasticities. ${ }^{3}$ We can compare if micro elasticities are in fact smaller than macro elasticities, without differences in methodology confounding the potential differences in micro estimates from different countries or differences between micro and macro level reactions.

Third, at the macro level, the model is also correctly specified (from the point of view of a static labour/earnings supply model), since we actually use mean marginal tax rates and virtual income from the data, rather than artificial constructs or average tax rates. In addition, the marginal tax rate we use also includes (in our main specifications) not only the increase in tax liability but also reductions in transfers and benefits; that is, we use the theoretically correct effective marginal tax rates. ${ }^{4}$ And fourth, we provide a separate analysis of intensive and extensive margin, both estimated at the micro and macro level.

The topic is of key importance to the Nordic model: The size of the public sector in the Nordic countries is among the largest in the world, and since tax distortions, other things equal, rise with the tax rate, the burden of financing the public sector can become very large. ${ }^{5}$ On the other hand, Rogerson (2007) and Blomquist, Christiansen, and Micheletto (2010) point out how the Nordic arrangement of

\footnotetext{
${ }^{3}$ We follow Chetty et al. (2012) and refer to macro elasticities if the source of the tax variation used in explaining labour supply is cross country comparisons; micro elasticities refer to findings identified from cross-sectional variation within a country

${ }^{4} \mathrm{We}$ also compare our macro estimates to the standard ways, used earlier in the literature, to estimate country-level responses to taxation.

${ }^{5}$ The well-known revenue-maximising top marginal tax rate for Pareto distributed top incomes is given by the formula $1 /(1+a * e)$ where $a$ is the Pareto Lorenz coefficient and $e$ is the elasticity of taxable income. With a typical Nordic value of $a$ equal to approximately 2 , the marginal tax rate on top incomes should not exceed 20 per cent if the elasticity is as high as 2, which belongs to the interval recommended by Keane and Rogerson (2012). The existing top marginal tax rate (including commodity taxes) in Sweden is currently around 70 per cent (Pirttilä and Selin, 2011). These differences dramatically highlight the issues at stake.
} 
subsidising goods that are used in conjunction with labour supply (such as childcare) counteract some of the harmful effect of taxation on work effort. Our data contain key Nordic countries, and we can compare their situation with interestingly different institutional settings, including the Anglo-Saxon countries.

Needless to say, the study also has some limitations. We cannot cover all OECD countries, since for some of the countries, suitable data is not available from LIS. We control for education level in the estimations, and therefore the impact of taxes which we measure do not contain the potential that tax changes can lead to changes in educational attainment. Our estimates capture, however, contemporaneous effects of learning-by-doing which is reflected in increases in wage rates. Unlike country-level studies, we do not have access to a microsimulation model to calculate effetive marginal tax rates, and we use data-driven semi-parametric methods to estimate marginal tax rates. However, this is also a methodological novelty, and we compare the estimated tax rates to other available information on tax systems in these countries.

The paper proceeds as follows. Section 2 provides a more detailed review of the existing papers on the micro-macro differences in elasticity estimates. Section 3 presents the theoretical background and empirical methodology, while Section 4 covers the data description and marginal tax rate estimation. The estimation results are presented in Section 5, and Section 6 concludes.

\section{Literature review}

This section surveys the emerging literature on the micro-macro differences in labour supply / earnings elasticities to understand what is the current status and whether important knowledge gaps remain. Notice that our aim is not to cover conventional microeconomic estimates on labour supply or taxable income (for surveys on these, see Meghir and Phillips (2010) and Saez, Slemrod, and Giertz (2012)).

\subsection{Starting point}

One of the starting points for this literature is the work by Prescott (2002, 2004). In Prescott (2004), he studies seven countries (the G-7 countries) Germany, France, Italy, Canada, United Kingdom, Japan and United States, over two time periods 1970-74 and 1993-96. The analysis contains 14 observations. Prescott departs from a standard growth model with a representative household and a representative firm, and he parameterises the value of leisure in such a way that the average labour supply the model generates matches the actual values in the data. Given this choice of preference parameter he obtains predicted work hours fairly close to actual work hours in 12 out of 14 cases. He obtains a labour supply elasticity of "nearly 3 when the fraction of time allocated to the market is in the neighbourhood of the current U.S. level".

Obviously, "nearly 3" sounds like a very large elasticity. However, Alesina, Glaeser, and Sacerdote (2005) show that Prescott's choice of parameter values implies an uncompensated labour elasticity of 
0.77. Relatedly, Chetty et al. (2011b) plot Prescott's data and fit a regression line to it. They then estimate a 'Hicksian' labour supply elasticity of 0.7 on the 14 observations. The discrepancy between the two elasticity estimates is that Prescott reports a Frisch elasticity, which depends upon the specific assumption about the utility function and the wealth-earnings ratio. ${ }^{6}$

Permanent differences in working hours between countries are, however, more closely related to static labour supply elasticities. Alesina, Glaeser, and Sacerdote (2005) calculate what uncompensated (Marshallian) labour supply elasticity Prescott's analysis gives rise to. Prescott's choice of a per-period utility function is $\log c_{t}+\alpha\left(\log 1-h_{t}\right)$, for which the Marshallian (uncompensated elasticity is $\eta_{t}^{\text {Marshallian }}=\frac{\alpha}{(1+\alpha)} \frac{M_{t}}{w_{t} h_{t}}=\frac{\alpha}{(1+\alpha)} \frac{c_{t}-w_{t} h_{t}}{w_{t} h_{t}}$. The parameterization in the Prescott study then implies that the uncompensated static elasticity is equal to $0.77 .^{7}$

As usual, one can use the Slutsky equation of $\frac{\partial h_{t}\left(w_{t}, u\right)}{\partial w_{t}}=\frac{\partial h_{t}\left(w_{t}, M_{t}\right)}{\partial w_{t}}-\frac{\partial h_{t}\left(w_{t}, M_{t}\right)}{\partial M_{t}} h_{t}$ to derive the compensated (Hicksian) elasticity, which for the Cobb-Douglas utility is $\eta^{\text {Hicksian }}=\eta^{\text {Marshallian }}+\frac{\alpha}{(1+\alpha)}$. When $\alpha=1.54$ we have that $\eta^{\text {Hicksian }}=0.77+0.61=1.38$ provided that the ratio between unearned income and after-tax earned income is 1.28 (following the assumptions used in the Alesina et al. paper). The Prescott analysis, thus, gives rise to a very large (relative to micro evidence) Hicksian elasticity, which is of key information, as tax distortions depend on this compensated elasticity.

Relatedly, Chetty et al. (2011b) plot Prescott's data and fit a regression line to it. They then estimate a 'Hicksian' labour supply elasticity of 0.7 on the 14 observations. They interpret this as a Hicksian elasticity as Prescott had assumed that the tax proceeds are handed back as lump-sum payments. Note that the estimate by Chetty et al. is only a half of the estimate implied by Prescott's work. In our paper, which builds on microeconometric techniques, we can directly model unearned income and do not need to assume anything regarding the extent of which tax revenues are paid back.

In fact, Prescott's functional form assumptions and choice of parameter values also imply sizeable income effects on labour supply. Against this background, it is an interesting feature of our study that we also estimate the response to changes in unearned income (even though one should keep in mind that our static labour supply model in some respects differs from Prescott's model).

Prescott's paper has given rise to a large debate. The basic conclusions were broadly supported by Ohanian et al. (2008), who used a similar methodology. Other researchers (e.g Nickell (2003) and Alesina, Glaeser, and Sacerdote (2005)) have pointed at the difficulties of teasing apart the impact of taxes from other factors that also affects aggregate work hours in a country. In addition, Ljungqvist et al. (2006) point out that the conclusions in Prescott (2002) change if one also considers that workers typically receive unemployment benefits (as a certain fraction of their work income) when unemployed.

\footnotetext{
${ }^{6}$ The Frisch elasticity of labour supply is derived holding marginal utility of consumption constant, whereas Hicksian estimates typically used by public finance economists are derived holding utility constant.

${ }^{7}$ Information on $\alpha$ and the ratio between consumption and after-tax earnings is sufficient to determine the Marshallian elasticity. Alesina et al. (2005) use the figure 2.28 for the ratio between consumption and after-tax earnings (i.e. a ratio between non-labor income and after-tax earnings of 1.27.). With Prescott's value of $\alpha$ of 1.54, the Marshallian elasticity then amounts to 0.77 .
} 


\subsection{Related papers}

Blundell, Bozio, and Laroque (2011) describe the long-run evolution of mean annual hours per worker, employment rate and the unconditional mean hours per individual on Labour Force Survey data from the U.S., the UK and France. Of particular interest is that total hours in the UK have decreased over a forty-year period, despite the fact that UK has adopted similar tax policy reforms as the US (e.g. in work tax credit policies). Blundell et al find that neither the intensive nor the extensive margin dominates in explaining the changes in total hours worked. The relative importance of the two margins differs across age, gender and family composition groups.

Davies and Henrekson (2004) exploit aggregate data for nineteen countries on outcome variables such as the ratio of employment to population of working age, annual hours worked per employed person and annual hours worked per adult of working age. According to their results, average tax rates are strongly negatively associated with working hours and employment rates in an OLS regression, but the coefficient becomes insignificant when country fixed effects are included.

The study by Piketty, Saez, and Stantcheva (2011), while not so much related to the literature on micro-macro elasticities, is interesting since it uses macro data to estimate taxable income elasticities at the top. The authors set up an optimal tax model in which top incomes respond through three channels: (1) the standard labour supply response, (2) the tax avoidance channel and (3) the compensation bargaining channel through efforts in influencing own pay setting. Importantly, bargaining efforts are zero-sum in the aggregate. Therefore, the optimal tax rate increases with the bargaining elasticity.

In the empirical part, Piketty et al analyse top income and top tax rate data in 18 OECD countries. They exploit the World Top Income Database combined with top income tax rate data starting in 1975. Piketty et al. find a strong correlation between the growth in top incomes and marginal tax cuts for top income earners. Higher top incomes did not, however, lead to higher GDP growth. Piketty et al interpret this pattern as consistent with low labour supply elasticities and large bargaining elasticities.

An alternative explanation to why hours have increased in the US and fallen in Europe is related to behavioural economics, namely the Veblen effect: When people compare their income level to that of top earners, a rise in income inequality can render people to supply more labour because of their effort to "keep up with the Joneses". Oh, Park, and Bowles (2012) use country-level data on working hours, taxes and top income shares and show, in a model with country and year fixed effects, how increases in top income shares are associated with increases in working hours. Moreover, taxes lose explanatory power for working hours when the top income share is added to the regression model.

The final paper that is relevant to the current paper, and perhaps also the closest one, is Bargain, Orsini, and Peichl (2014). They have collected micro-data on work hours, wages and taxes and benefits (microsimulation) from 17 European countries and the US. For the European countries the EUROMOD microsimulation model has been used, whereas TAXSIM has been used for the US. The motivation for the paper is to make a large-scale international comparison of elasticities, while netting out possible differences due to methods, data selection and the period of investigation. To this end, Bargain et al. 
estimate the same structural discrete-choice labour supply model on all these data sets, with separate models for couples and singles. The wage elasticities vary less between the countries than previously thought. The resulting differences are interpreted as consequences of heterogeneous preferences.

Since our paper is more related to the micro-macro differences, the Bargain et al. study and our work are quite complementary. There are also many significant differences in the approaches taken. For example, we use the Blundell et al. repeated cross-section estimator, whereas they build a discrete choice labour supply model that relies on cross-sectional variation for identication, and we utilise data from a much longer time span.

\section{Data}

\subsection{General features and sample selection}

Our data are from the Luxembourg Income Study database, LIS, which collects household- and individuallevel data on household income, taxes paid and transfers received, working hours (for a subset of countries) and consumption (Luxembourg Income Study Database (LIS), 2014). The benefit of the data is that LIS has invested a large amount of work to make the data comparable across countries and across years. LIS provides income, labour market, and demographic data that have been harmonised in to a common template, so the contents of the variables are as comparable as cross-country data, across time, can get. ${ }^{8}$

Another benefit of the data is that it spans over four decades; the data we use start from the beginning of the 1970s. It also covers a wide range of different type of countries; we focus on developed (OECD) countries. Not all information is available for all countries, however. A main dividing line is between 'gross' and 'net' data sets. Gross data sets record all market and non-market income sources gross of income taxes, whereas net data, as the name suggests, include only information on income sources net of taxes withheld. We can, of course, use only those countries that provide gross data, in LIS parlance. In addition, even if household-level data exist, individual-level earnings data are not always available. These restrictions limit the number of countries we cover to 13. These include, most notably, key Anglophone countries (the U.S., the UK, Australia), the Scandinavian countries, and some Central European countries (such as Germany and Netherlands). ${ }^{9}$ The countries in our data are interestingly different in their institutional characteristics and the role and size of the government in the economy.

As mentioned in the introduction, the data are repeated cross sections from a number of waves. The exact year corresponding to a particular wave varies somewhat across countries. Table 1 lists the countries and years in our data.

\footnotetext{
${ }^{8}$ For information on data harmonisation, see http://www.lisdatacenter.org/wp-content/uploads/ our-lis-documentation-harmonisation-guidelines.pdf.

${ }^{9}$ Prior to 1990 West Germany was a LIS country. For the post-1990 samples for re-unified Germany, we excluded the formerly East German Länder.
} 
We have two key dependent variables in our empirical analysis: annual work hours and labour force participation. The variable for annual work hours is created from survey questions on weekly hours and number of weeks worked per year. We can use information on work hours for seven countries: Australia, Canada, Germany, Netherlands, Sweden, U.K and U.S. ${ }^{10}$

The earnings variable, which is available for all 13 countries, includes both monetary and nonmonetary compensation. For a majority of countries, the earnings variable comes from surveys, but for some countries, especially the Nordic ones, it is based on register data. The earnings variable is used both in the intensive and in the extensive margin analysis. In the extensive margin analysis, we define labor force participation as having positive earnings. In the intensive margin analysis, the earnings variable is used to construct the gross wage. ${ }^{11}$

We have limited our analysis to four types of households, single persons (with and without children) and couples (again, with and without children), to be able to more cleanly estimate how taxes and transfers vary with income. ${ }^{12}$ The estimation samples for the intensive margin analysis (work hours and earnings) and the extensive margin analysis are selected in slightly different ways. We impose the following restrictions on the 'intensive margin sample'. First, we only include individuals aged 25-54, so that early retirement is not an issue. Second, we exclude individuals who earn less than the 20th percentile, where percentiles are defined based on the distribution of earnings in country $c$ in period $t .{ }^{13}$ Due to variations in top-coding of the LIS data, we also exclude those with earnings exceeding the 97.5 percentile in country $c$ in period $t$.

In the extensive margin analysis, we include all individuals aged 25-64 in the sample. In the extensive margin analysis, it is in fact desirable to also capture the retirement margin (as emphasised by Rogerson and Wallenius, 2009).

The model below in Section 4 lays out in more detail the requirements of the empirical model. In terms of data, we also need information on capital income. Demographic variables (sex, education, age, household type) are also used.

\footnotetext{
${ }^{10} \mathrm{We}$ also have hours data for Finland in 1991 and Belgium in 1997. However, as the estimation framework builds on changes in taxes across time and groups we leave Finland and Belgium out from the hours regressions.

${ }^{11}$ The gross hourly wage rate is obtained by dividing yearly earnings by yearly work hours.

${ }^{12}$ This means that we exclude households that include adults that are not in the nuclear family.

${ }^{13}$ It is common in the empirical tax literature to impose a lower income limit on the estimation sample, see e.g. Gruber and Saez (2002).
} 


\subsection{Tax variables}

A key variable in the intensive margin analysis is the effective marginal tax rate. ${ }^{14}$ The slope of an individual's budget constraint is not only determined by the statutory income tax schedules, but also by the transfer systems in place. To our knowledge, there is no microsimulation model that can be used to compute effective marginal tax rates for all the countries in all the years in our data. We therefore proceed in the following way. For the purpose of calculating the statutory income tax schedules, we build a small tax calculator. For a majority of countries we exploit information on segment limits and rates (for both central government and subcentral government taxation) provided by the OECD from 1981 and onwards. ${ }^{15}$ The OECD information applies to singles without dependents. For countries and time periods where the OECD information is missing or insufficient, we have collected information from alternative sources, e.g. from the library of the International Bureau of Fiscal Documentation (IBFD) in Amsterdam and the European Tax Handbooks, various editions. The coded tax functions are then used to compute marginal tax rates, taking into account differences between joint vs. individual taxation and global vs. dual income taxation.

Needless to say, the tax rates calculated in this way are not ideal measures of the individuals' marginal incentives to earn income. A limitation of our data is that information on deductions are absent. As mentioned above, we do not observe taxable income net of deductions, which is the relevant base for income taxation. As a consequence, given that marginal tax rates typically are increasing in income, we believe that the true level of statutory marginal tax rates facing taxpayers is lower than the one we have calculated.

It is considerably more challenging to collect information on the transfer systems for all countries/years. For the purpose of calculating the marginal effects arising from the transfer systems, we therefore suggest a data-driven approach, where we fit a non-parametric regression on labour income to predict marginal effects. We use the locfit package in $\mathrm{R}$ to carry out these regressions (for information on these estimation techniques, see Chapter 6.1 in Loader, 1999). The procedure estimates local polynomial regressions, regressing taxes on income; the estimated first derivative then represents the marginal rate of transfer withdrawal as earnings increase. The benchmark regressions use a third degree polynomial, a nearest-neighbour bandwidth of 0.7 (that is, 70 per cent of observations are used at every evaluation point) and a Gaussian weighting function. We also experimented with alternative bandwidths and polynomial degrees.

Taxes and transfers are calculated/estimated seperately for four different household types, namely

\footnotetext{
${ }^{14}$ Our measure of taxes does not include social security payments. One reason for this choice is that while the data has household or individual level information on the social security payments made by the employees, the social security payments paid by the employers would need to be imputed. Countries also differ significantly in the division of these payments between employees and employers, and this division should not really matter for tax incidence. For equal treatment of countries, we decided not to take these payments into account. For macro regressions, we also calculate alternative tax functions that take into account proportional consumption taxes. The rates of these vary only at the country level.

${ }^{15}$ This information is available at http://www. oecd.org/tax/taxpolicyanalysis/oecdtaxdatabase. htm\#pir.
} 


\begin{tabular}{|c|c|}
\hline Country & Years \\
\hline Australia & 1985(h), 1989(h) \\
\hline Belgium & $1992,1997(h)$ \\
\hline Canada & 1981, 1987(h), 1991(h), 1994(h), 1997(h), 1998(h), 2000(h), 2004(h) \\
\hline Czech republic & 1996,2004 \\
\hline Denmark & $1987,1992,1995,2000,2004$ \\
\hline Finland & 1987, 1991(h), 1995, 2000, 2004 \\
\hline Germany & 1984, 1989(h), 1994(h), 2000(h), 2004(h) \\
\hline Israel & $1992,1997,2001,2005$ \\
\hline Netherlands & $1987,1999(h), 2004(h)$ \\
\hline Norway & 1986, 1991, 1995, 2000, 2004 \\
\hline Sweden & 1992(h), 1995(h), 2000, 2005 \\
\hline United Kingdom & 1991(h), 1995(h), 1999, 2004 \\
\hline United States & 1974(h), 1986(h), 1991(h), 1994(h), 1997(h), 2000(h), 2004(h) \\
\hline
\end{tabular}

Note: (h) indicates availability of data on annual work hours.

couples and singles with and without children (see Appendix A for a further discussion).

Figure 1 depicts an example of marginal tax rates and effective marginal tax rates used in the analysis. Note that the shape of these two functions are completely different: marginal tax rates are monotonically increasing, whereas it is well known that effective marginal tax rates take a $U$ shaped form: they are highest at the bottom of the income distribution because of tapering off of benefits. This means that the real incentives, taking into account transfer systems, can be completely different to many individuals than a typical analysis, using solely statutory taxes, would suggest.

For the extensive margin analysis, we are interested in participation tax rates rather than marginal tax rates. These are obtained by using cell-level estimates of net taxes (taxes less transfers) for those who work and whose who do not but have otherwise similar characteristics; the difference is taken to measure the change in net taxes on becoming employed. A further description is to be found in Appendix B.

\section{Empirical model}

\subsection{Basic model}

As mentioned above, our aim is to utilise micro data from several countries and several time periods to estimate both 'micro' and 'macro' elasticities using the same data source. Following Chetty et al. (2011b), we use the terms 'micro' and 'macro' elasticities to refer to the sources of variation used to estimate the elasticities. When the elasticity is identified based on quasi-experimental variation between different groups in a single country we refer to the estimated elasticity as a 'micro' elasticity. When the elasticity is identified by cross-country and time variation, the estimated elasticity is a 'macro' 
Figure 1 Marginal and effective marginal tax rates, Finland and Sweden 1995-2004
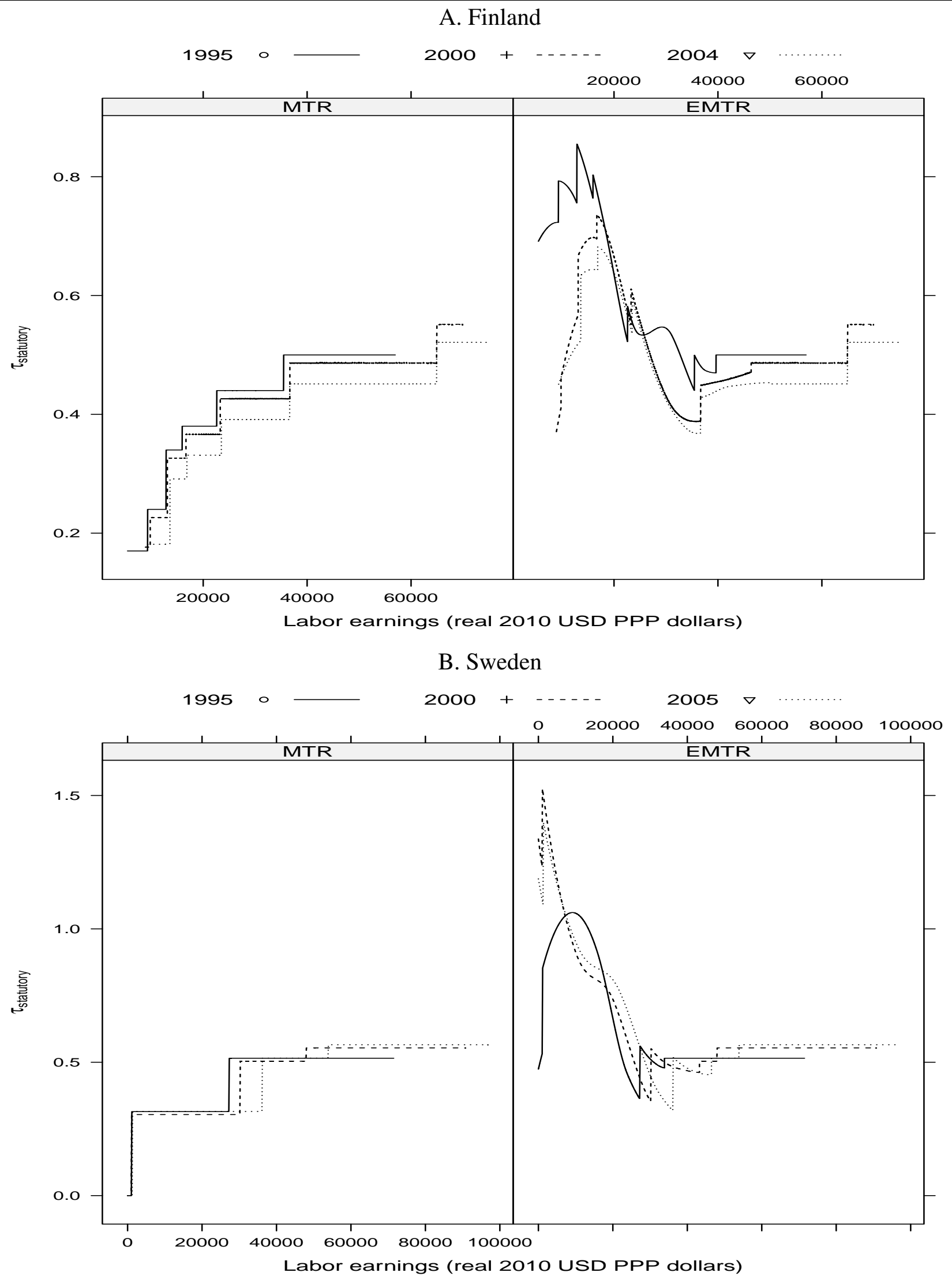
elasticity.

In this section, we elaborate on how to estimate micro elasticities for a single country. We start off from the standard static labour supply model, where individuals maximise the utility function $U=$ $U(c, h)$ with respect to consumption, $c$, and labour supply in terms of annual hours, $h$, subject to the linearised budget constraint $c=(1-\tau) w h+R$, where $w$ is the gross hourly wage rate, $\tau$ is the marginal tax rate and $R$ is virtual income. Virtual income can be computed as $R=m+\tau z-T(z)$, where $m$ is non-labour income (e.g. the income of the spouse and capital income), $z=w h$, and $T(z)$ is the income tax function. ${ }^{16}$ The hourly wage rate has been obtained by dividing annual earnings by annual hours. In accordance with e.g. Blundell, Duncan, and Meghir (1998), we assume the following labour supply function;

$$
h_{i t}=\beta \ln \left(1-\tau_{i t}\right) w_{i t}+\gamma R_{i t}+\varepsilon_{i t},
$$

where $i$ is an individual index and $t$ is a time index. The uncompensated labour supply elasticity in country $c$ (evaluated at mean hours in country $c$ ) is given by $\beta / \bar{h}$, where $\bar{h}$ is mean hours in country $c{ }^{17}$ The equation is estimated on all $i$ who supply positive hours.

Suppose that we were to estimate equation 1 by OLS. As both of the right-hand side regressors are correlated with $\varepsilon$ and so are endogenous, estimates of both of the parameters are biased. The most obvious reason is that both $\tau$ and $R$ are direct functions of $z=w h$. An additional reason is that unobserved variables (e.g., tastes for work and savings) might affect work hours $h$, the gross wage rate $w$ and the level of non-labour income $m$ simultaneously.

The repeated cross section element of our data allow us to compare groups of individuals over time and, thereby, address these endogeneity issues by constructing instruments. Following Blundell, Duncan, and Meghir (1998), we partition the sample into group cells based on country, gender, age and education level. The key idea behind the grouping procedure is to compare otherwise similar groups of individuals who have been affected differently by tax reforms (the difference-in-difference idea) while retaining the ambition to estimate structurally meaningful parameters (in this case $\beta$ and $\gamma$ ). ${ }^{18}$

Let $g$ denote group cell. Suppose that $\varepsilon_{i t}=\alpha_{g}+\mu_{t}+\eta_{i t}$, where $\mathrm{E}\left[\eta_{i t} \mid h_{i t}>0, g, t\right]=0$. According to this assumption unobserved heterogeneity, conditional on $g$ and $t$, can be captured by a permanent group effect $\alpha_{g}$ and a time fixed effect $\mu_{t}$. This assumption can also be modified in such a way that it allows e.g. for education group specific linear time trends. Let $\omega_{g t}$ be a vector that contains the full set of interactions between group and time. By assumption, these are uncorrelated with $\eta_{i t}$. This is the

\footnotetext{
16 The virtual income consists of the individual's non-labour income and a term that takes into account that inframarginal units of supplied income is taxed at other rates (typically lower rates) than income supplied at the margin. Formally, for a general nonlinear tax system $T(z)$, virtual income at a point $\mathrm{x}$ is defined as the intersection between the tangent (i.e linear approximation) of the budget set $c(z)=z-T(z)$ at $x$ and the consumption axis.

${ }^{17}$ The compensated labour supply elasticity, which is the relevant parameter for deadweight loss calculations, can be obtained through the Slutsky relationship.

${ }^{18}$ Needless to say, it is not entirely unrestrictive to assume that $\beta$ and $\gamma$ are homogenous across demographic groups. It is therefore important to note that we also estimate our models for males and females separately.
} 
central exclusion restriction for identification. We can then estimate

$$
h_{i t}=\beta \ln \left(1-\tau_{i t}\right) w_{i t}+\gamma R_{i t}+\alpha_{g}+\mu_{t}+\eta_{i t}
$$

by two-stage least squares (2SLS) while using $\omega_{g t}$ as excluded instruments for $\ln \left(1-\tau_{i t}\right) w$ and $R_{i t}$. Crucially, both the order condition and the rank condition for identification need to hold. The order condition requires us to have at least as many instruments as endogenous regressors (in our case, two). The rank condition requires that net wage rates and virtual incomes must both change at different rates for different groups over time. As the variation in the second stage equation is entirely at the group level, equation (2) can also be estimated by collapsing the data into time-specific group averages of the relevant variables. ${ }^{19}$ We then estimate

$$
\overline{h_{g t}}=\beta_{\text {micro }} \overline{\ln \left(1-\tau_{g t}\right) w_{g t}}+\gamma_{m i c r o} \overline{R_{g t}}+\alpha_{g}+\mu_{t}+\eta_{g t}
$$

by GLS, using group size as weights. Using either equation (2) or (3) yields identical results.

One should recognise that tax reforms are not the sole source of identifying variation when estimating (3). Identification also comes from differential growth in gross hourly wage rates. ${ }^{20}$

\subsection{Macro elasticities}

We will now highlight the country-time dimension of our data. Equation 2 can also be estimated by 2SLS using the interactions between the country dummies and time dummies as excluded instruments. Let $c$ be a country index and let $\alpha_{c}$ be a country-specific fixed effect. The macro elasticity can be estimated by collapsing the data into year-specific country averages and running the regression

$$
h_{c t}=\beta_{\text {macro }} \ln \left(1-\tau_{c t}\right) w_{c t}+\gamma_{\text {macro }} R_{c t}+\alpha_{c}+\mu_{t}+\eta_{c t}
$$

Since it is common in the macro literature not to weight by country size, we estimate (4) by OLS rather than GLS as a baseline. Thus, we let the weights within each country sum to one. The results from those regressions can be readily compared with earlier macro-level regressions.

\subsection{Micro-macro estimates}

A third alternative, which can be characterised as a bridge between micro and macro estimation, is to use micro data for several countries in the same regression. While retaining the above notation, we

\footnotetext{
${ }^{19}$ See Angrist and Pischke (2008, section 4.1.3.) for an interesting discussion about IV estimation on grouped data.

${ }^{20}$ It is important for the interpretation of the estimated parameters whether or not the tax- and wage changes used for identification are anticipated by the agents. Here we make the standard assumption that the tax- and wage changes are unanticipated. Typically, the time difference between two waves in a given country is several years (see Table 1). Therefore, we believe that this is a reasonable assumption.
} 
write the regression equation as

$$
h_{g c t}=\beta_{\text {micromacro }} \ln \left(1-\tau_{g c t}\right) w_{g c t}+\gamma_{\text {micromacro }} R_{g c t}+\alpha_{c g}+\mu_{t}+\eta_{g c t},
$$

which we estimate by GLS. To achieve comparability with the macro regressions, we normalise the weights in such a way that they sum to 1 for country $c$ in year $t$. The elasticity is now identified by variation both between groups (defined by sex, age and education) and between countries.

One can add additional controls, such as country-specific trends to this equation. In this case, the equation above is rewritten as $\varepsilon_{i t}=\alpha_{g}+\mu_{t}+\delta_{c} \times$ trend $+\eta_{i t}$. In words, unobserved heterogeneity, conditional on $g$ and $t$, can be captured by a permanent group effect $\alpha_{g}$, a time fixed effect $\mu_{t}$ and a country-specific linear time trend, $\delta_{c} \times$ trend. Education-specific trends can be added in similar spirit.

The practical complication that arises in the estimations is that we need to take into account spousal income in the regressions, and countries have different solutions to family taxation (joint vs individual taxation). Also, capital income is treated in different ways (income taxation can either be comprehensive or then capital income is taxed using a different schedule, as in a dual income tax). In Appendix A, we describe the way budget constraints, including virtual income, are calculated for these different cases.

\subsection{The extensive margin}

The analysis above was limited to the reaction at the intensive margin (for those who supply a positive amount of hours). We now model separately the individual's decision whether or not to work. In the extensive margin model, each individual chooses between two points in the consumption-earnings space. They choose between consumption at zero earnings and at the earnings level they potentially would earn if they entered the labour market.

Following e.g. Immervoll et al. (2007), suppose the utility when working takes a quasi-linear form $U=c-v(z)$, where $v(z), v(0)=0$, reflects the disutility of earnings supply. ${ }^{21}$ Let the subscripts $w$ and $n w$ denote consumption and earnings in the state of work and non-work, respectively. The utility from not working is just $c_{n w}$. Therefore, the individual works if $c_{w}-c_{n w}>v\left(z_{w}\right)$. Consumption when working is given by $c_{w}=z_{w}-T\left(z_{w}\right)+q$ where $T(z)$ denotes the transfers received and taxes paid and $q$ other household income. Consumption when not working is $c_{n w}=-T(0)+q$. The condition for working can therefore be written in terms of tax variables as

$$
z_{w}-\left[T\left(z_{w}\right)-T(0)\right]-v\left(z_{w}\right)>0
$$

which can also be written as

$$
(1-a) z_{w}-v\left(z_{w}\right)>0
$$

\footnotetext{
$21 v(z)$ can be interpreted broadly to also accommodate fixed costs of working. To ease notation we leave the term capturing the fixed costs out.
} 
where $a=\left[T\left(z_{w}\right)-T(0)\right] / z_{w}$ is the participation tax rate, i.e. the increase in taxes and the loss in benefits, relative to gross earnings, when the individual starts to earn positive labour income. For linear probability models, the empirical counterpart of equation (7), the probability to work $P(\text { work })_{i, t}$ for the individual $i$ and at period $t$ is 22

$$
P(\text { work })_{i t}=\alpha+\beta_{\text {ext }} *\left(1-a_{i t}\right) z_{w, i t}+\varepsilon_{i t},
$$

where $P($ work $)$ is defined to take on the value of 1 if the individual supplies earnings exceeding zero. The participation elasticity, i.e. the percentage change in the probability to work from a percentage change in $1-a$, can be calculated as $\beta_{\text {ext }} \times[(1-a) z / P($ work $)]$. In similarity with the hours regressions, identification of $\beta$ does not only rely on the tax variable $a$, but also on imputed potential earnings in the state of work.

Similarly to the intensive margin case, we assume that the error term takes the form $\varepsilon_{i t}=\alpha_{g}+\mu_{t}+$ $\eta_{i t}$, where $\mathrm{E}\left[\eta_{i t}\right]=0$. Equation 8 could be estimated by 2SLS using the interaction between the group and time dummies as instruments for $\left(1-a_{i t}\right) z_{w, i t}$. Equivalently, one can estimate the group-averaged equation.

$$
\overline{P(\text { work })_{g t}}=\beta_{\text {ext }} \overline{\left(1-a_{g t}\right) z_{g t}}+\alpha_{g}+\mu_{t}+\eta_{g t}
$$

by GLS. As in the intensive margin case, the analysis can also be conducted at the macro level, aggregating equation (9) to country level.

There are two main challenges involved in estimating the financial gain of working, $\left(1-a_{i t}\right) z_{w, i t}$ : imputing earnings in the state of work and estimating the tax and transfer function. In Appendix B, we elaborate more on how we do this.

\section{Results}

\subsection{Working hours}

The results on working hours are only available for seven countries for which at least two cross sections of data on hours are available. The country-specific estimates for all individuals, as well as men and women separately, corresponding to equation (3), are presented in Table 2. Various specifications of the macro level hours estimation results, corresponding to equation (4), are presented in Table 3, whereas the micro-macro estimates of equation (5) are in Table 4. Throughout the results section, we report elasticities rather than regression coefficients. For work hours, we report the (uncompensated) hours elasticity with respect to the net wage and the hours elasticity with respect to (virtual) non-labour income. Reported standard errors have been obtained by the delta method.

\footnotetext{
${ }^{22}$ Formally, this derivation assumes that $v(z)$ is uniformly distributed. It would perhaps have been more realistic to assume a normal distribution and, hence, arrive at a probit model. This would not, however, have been tractable from a statistical point of view owing to the incidental parameter problem.
} 
The results from countrywise regressions indicate that the net wage elasticities are either insignificant or positive. The most interesting cases are perhaps the U.S. and Canada, where we use 7 years of data (and throughout obtain significant net wage elasticities). For Canada, we estimate an average net wage elasticity of 0.38 . When estimating the same model separately for males and females, it turns out that the point estimate for the male elasticity (0.51) is larger than the point estimate for the female elasticity (0.19). For the U.S., we estimate an overall elasticity of 0.28 . However, for the U.S., the female elasticity $(0.23)$ is estimated to be larger than the male elasticity $(0.13){ }^{23}$ It is a common reading of the labour supply literature that female elasticities are larger than male elasticities.

For other countries, the net wage elasticities are insignificant. In general, virtual income elasticities are insignificant as well. However, in those cases where the estimate is indeed significant (women in Australia, males in Sweden and women in the UK) it takes on the expected negative sign, consistent with the widespread notion that leisure is a normal good.

Let us now turn to the macro regressions for hours reported in Table 3. These regressions contain 26 observations that are aggregates of the cells used in the micro regressions. ${ }^{24}$ In column 1 we report a net wage elasticity of around 0.2 from a regression where we only include the log net wage and virtual income. In the key specification that includes both country and year dummies (column 4), the net wage elasticity is estimated to be as large as 0.64 and the estimate is significant.

Remember that identification comes from the interaction between country and year. In fact, since countries and years do not fully overlap (see Table 1), the estimate reported in column 4 can be obtained by using a subset of 13 observations only. When we use LIS wave dummies instead of year dummies, considerably more observations contribute to the identifying variation. A LIS wave typically spans 3-4 calender years. As can be inferred from column 5, the net wage elasticity drops from 0.64 to 0.37 , but it is still very significant. It should be emphasized that the regressions with waves rather than year dummies are more robust to small changes in the specification. ${ }^{25}$ When we allow for heterogenous responses for males and females (columns 6 and 7), we obtain a larger point estimate for males.

In the key specification (column 4), the estimated virtual income elasticity takes on the 'wrong' sign and is borderline significant. As far as we know, this is the first time the virtual income regressor has been included in a cross-country regression. Since virtual income contains components such as spousal income and asset income, it is perhaps not surprising that we get a positive sign when we exploit the interaction between time and country to recover the virtual income elasticity. Importantly, the estimated

\footnotetext{
${ }^{23}$ At first sight, it might appear odd that the overall elasticity for the U.S. exceeds both the male and female elasticity estimates. However, one should keep in mind that these estimates are identified in different ways. When estimating the overall elasticity, the interaction between gender status and time contributes to the identifying variation, which is not the true for the gender-specific regressions.

${ }^{24}$ In the micro regressions, we exclude cells that contain less than 50 observations. These are, however, included when constructing the aggregated macro sample. Results are virtually identical if one excludes cells with less than 50 observations before aggregating.

${ }^{25}$ If one runs the main regression 7 times while omitting one country each time, the results with wave and country dummies are in the range 0.29 to 0.43 . Doing the same excercise with year and country dummies, we get more unstable estimates when leaving out Canada and the U.S.
} 
net wage elasticities are throughout virtually unaffected by dropping the virtual income term from the macro regression.

In Table 4, we report estimates from the 'micro-macro' regressions, where we exploit both crosscountry and cell-level variation for identification. In column 2, where we include both the full set of year dummies and country-cell dummies, the net wage elasticity is estimated to be around 0.3 (highly significant). We will refer to this estimate as the 'micro-macro elasticity'. ${ }^{26}$

When we control for the share of a certain household type in the cell and for education-groupspecific linear time trends, nothing happens to the estimated net wage elasticity. On the other hand, the virtual income elasticity grows in the 'wrong' direction. ${ }^{27}$ Across all specifications, the net wage estimates are significant at a level of one percent. In contrast to the 'macro' regressions, the 'micro-macro' regressions are insensitive to controlling for wave dummies instead of year dummies, see column 5 .

In column 4, we report results from a specification where we control for the country-time variation by including interaction terms for country and year dummies. When only within-country variation is used to identify the net wage elasticity, it falls to $0.23 .^{28}$ In similarity with the macro regressions, we obtain larger net wage elasticities for males than females, see columns 6 and 7.

The working hours regressions can be summarised in the following way. The point estimate of the 'average micro elasticity' of 0.23 is lower than the point estimate of the 'micro-macro elasticity' of 0.3 , which in turn is lower than the 'macro elasticity', where the point estimates are 0.64 with year dummies and 0.37 with wave dummies. The difference between the 'average micro elasticity' and the macro elasticity with year dummies appears to be statistically significantly different from zero ( $p$-value 0.02 , assuming zero correlation) but that between the 'average micro elasticity' and the macro elasticity with wave dummies is not (( $p$-value 0.51 , assuming zero correlation $).{ }^{29}$

\subsection{Participation}

Results on participation are derived from estimating equation (6). We present those in the form of a participation elasticity, i.e. the elasticity of the probability to have positive earnings with respect to an increase in the difference of disposable income when in work versus when not working. Note that income when not working contains an average income of the type of person (cell average) in question when out of work, and it also includes pension income. Thus, the participation elasticities also capture the retirement margin to some extent.

\footnotetext{
${ }^{26}$ In column 2-7 we always control for the interaction between age, education, sex and country.

${ }^{27}$ We have defined four household types: couples with kids, couples without kids, singles with kids and, finally, singles without kids.

${ }^{28}$ Alternatively, one can of course also control for the interaction between age, education, sex and time so that the elasticity is identified off from the country-time interaction only. In this case, the net wage elasticity is unaltered (0.3), but the virtual income elasticity is larger.

${ }^{29}$ The $p$-values we report assume a zero correlation, but the statistical significance of the differences is unaffected by allowing the correlation to vary between -1 and 1 in both cases.
} 
Table 2 Countrywise hours regression results

\begin{tabular}{|c|c|c|c|}
\hline & A. All & B. Men & C. Women \\
\hline \multicolumn{4}{|l|}{ Australia } \\
\hline \multirow[t]{2}{*}{ Net wage elasticity } & 0.011 & 0.383 & -0.282 \\
\hline & 0.149 & 0.377 & 0.146 \\
\hline \multirow[t]{2}{*}{ Virtual income elasticity } & -0.080 & 0.146 & $-0.190 *$ \\
\hline & 0.095 & 0.174 & 0.077 \\
\hline $\mathrm{Nr}$ of cells & 32 & 17 & 15 \\
\hline \multicolumn{4}{|l|}{ Canada } \\
\hline \multirow[t]{2}{*}{ Net wage elasticity } & $0.381 * * *$ & $0.506 * * *$ & $0.189 *$ \\
\hline & 0.048 & 0.056 & 0.074 \\
\hline \multirow[t]{2}{*}{ Virtual income elasticity } & -0.135 & -0.283 & -0.038 \\
\hline & 0.077 & 0.154 & 0.081 \\
\hline $\mathrm{Nr}$ of cells & 126 & 63 & 63 \\
\hline \multicolumn{4}{|l|}{ Germany } \\
\hline \multirow[t]{2}{*}{ Net wage elasticity } & 0.105 & 0.081 & 0.163 \\
\hline & 0.065 & 0.099 & 0.100 \\
\hline \multirow[t]{2}{*}{ Virtual income elasticity } & 0.047 & 0.070 & -0.002 \\
\hline & 0.077 & 0.133 & 0.080 \\
\hline $\mathrm{Nr}$ of cells & 70 & 36 & 34 \\
\hline \multicolumn{4}{|l|}{ Netherlands } \\
\hline \multirow[t]{2}{*}{ Net wage elasticity } & $0.249 * * *$ & -0.483 & 0.043 \\
\hline & 0.063 & 0.267 & 0.246 \\
\hline \multirow[t]{2}{*}{ Virtual income elasticity } & 0.115 & -0.122 & 0.074 \\
\hline & 0.088 & 0.110 & 0.850 \\
\hline $\mathrm{Nr}$ of cells & 33 & 18 & 15 \\
\hline \multicolumn{4}{|l|}{ Sweden } \\
\hline \multirow[t]{2}{*}{ Net wage elasticity } & 0.240 & $0.288^{*}$ & 0.233 \\
\hline & 0.169 & 0.134 & 0.380 \\
\hline \multirow[t]{2}{*}{ Virtual income elasticity } & -0.267 & $-0.661 * *$ & -0.105 \\
\hline & 0.418 & 0.221 & 0.617 \\
\hline $\mathrm{Nr}$ of cells & 36 & 18 & 18 \\
\hline \multicolumn{4}{|l|}{ United Kingdom } \\
\hline \multirow[t]{2}{*}{ Net wage elasticity } & -0.576 & -1.657 & 1.406 \\
\hline & 0.975 & 1.372 & 0.784 \\
\hline \multirow[t]{2}{*}{ Virtual income elasticity } & -0.315 & 0.291 & $-0.641 * * *$ \\
\hline & 0.235 & 0.854 & 0.129 \\
\hline $\mathrm{Nr}$ of cells & 35 & 18 & 17 \\
\hline \multicolumn{4}{|l|}{ United States } \\
\hline \multirow[t]{2}{*}{ Net wage elasticity } & $0.280 * * *$ & $0.130^{*}$ & $0.228 * * *$ \\
\hline & 0.029 & 0.057 & 0.068 \\
\hline \multirow[t]{2}{*}{ Virtual income elasticity } & -0.046 & -0.064 & -0.044 \\
\hline & 0.040 & 0.068 & 0.049 \\
\hline $\mathrm{Nr}$ of cells & 126 & 63 & 63 \\
\hline
\end{tabular}

Note: Dependent variable: annual working hours. Cells are defined based on age, education and sex. Cells with less than 50 observations are excluded. Individuals with earnings lower than the 20th percentile in each country/year are excluded from the underlying data. The reported estimates are the elasticities of working hours with respect to (1-effective marginal tax rate)*gross hourly wage and virtual income. All regressions contain the full set of cell dummies and year dummies. Standard errors reported below the estimates are robust to heteroscedasticity. * indicates significance at $10 \%$ level, $* * 5 \%$ level and *** at $1 \%$ level.

Source: Authors' estimations. 


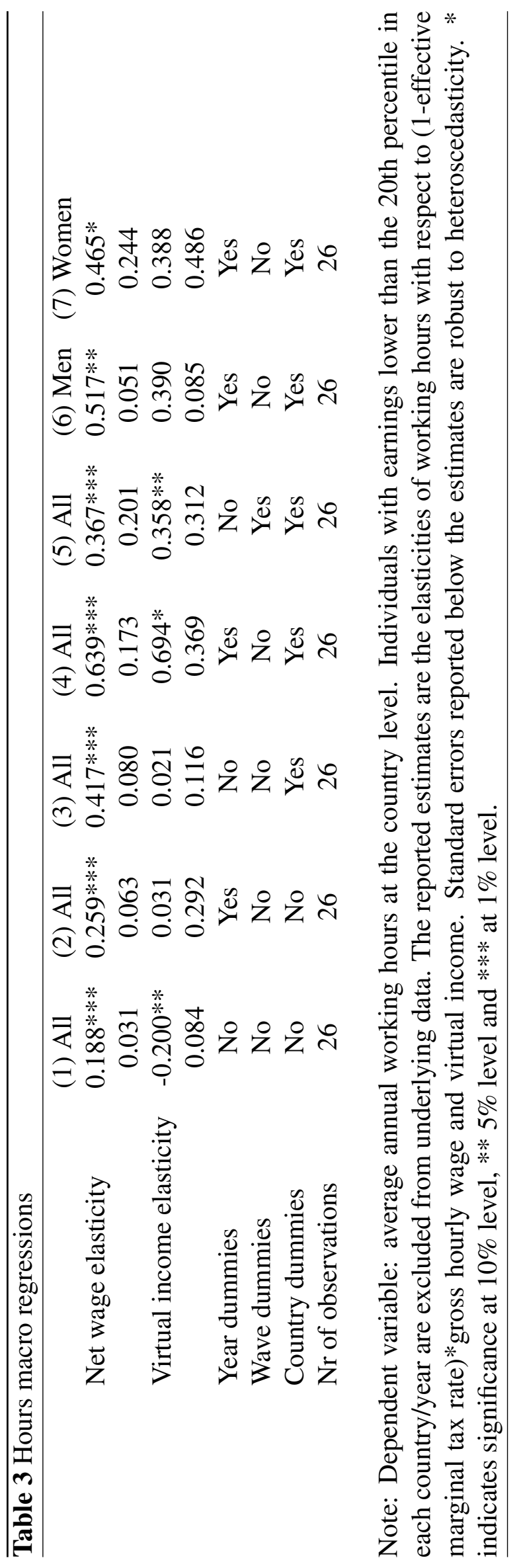




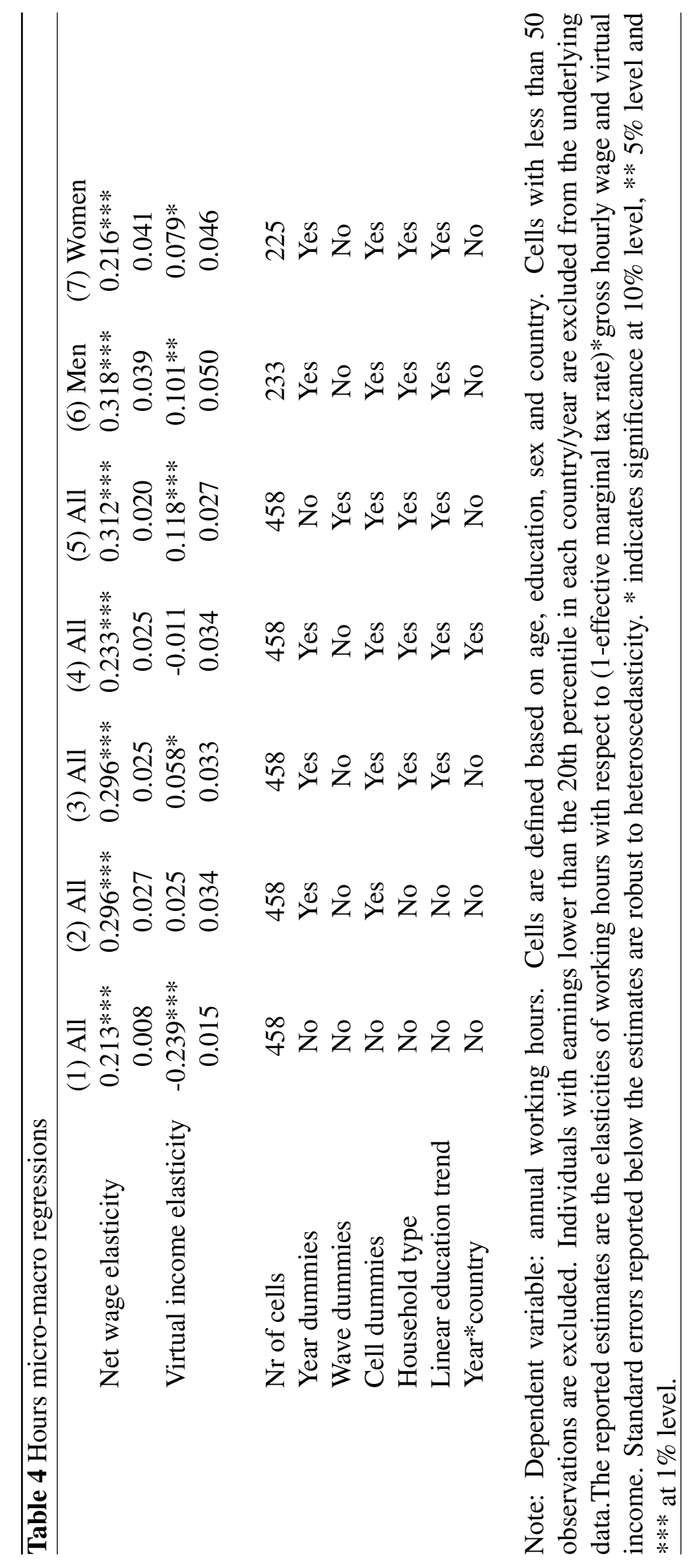


The results from Table 5 indicate that the participation elasticities range from 0-0.4 for all individuals, with many that are not statistically significantly different from zero. The size of the estimates are well in line with the existing estimates in the literature. ${ }^{30}$

The macro-level participation elasticity in the ideal specification with the full set of year dummies and country fixed effect, reported in Table 6, is not statistically significantly different from zero. However, one needs to remember that the number of observations in the country-level regressions is quite limited (albeit larger than in many earlier papers); the results therefore need to be interpreted cautiously. Nevertheless, these results indicate that macro-level participation elasticities do not appear to be greater than corresponding elasticities at the micro level, even when taking into account the retirement margin, affecting the length of the working life. As reported in column 5, we have also estimated the model on the smaller sample that was used in the hours analysis, where we obtained a significant intensive margin elasticity.

When identification arises both from cross-country and cross-sectional sources (see Table 7), the estimate is statistically significant without any controls or when education-specific trends are added. Here we have the expected result that the elasticity is greater for women than for men. In the basic specification with only cell, country and time fixed effects, the micro-macro estimate (Column 2) is very close to the mean of the micro estimates (Column 5) and it is not statistically significant. Neither is it for the same specification for the hours sample.

Similarly as in the hours regression case, we have also conducted several robustness checks. First, we have taken into account also consumption taxes from McDaniel (2012) in the micro-macro and macro level analysis. Taking into account these taxes in the participation analysis led to somewhat smaller estimates. Second, we dropped one country at a time from the micro-macro and macro level analyses. Results on participation are insensitive to these changes. Third, instead of having the net financial gain in levels as the key explanatory variable, we have run all regressions with the log of the net financial gain at the right hand side. This change leaves the qualitative results fairly similar, but it raises somewhat the point estimates. For example, the micro-macro elasticity in Column 3 raises from 0.031 to 0.086 ; and many other other participation elasticities also rise by 5 percentage points. We believe this is natural as the log specification gives a larger weight to low income earners, whose participation elasticity is likely to be higher.

Finally, we have also used the Blundell, Duncan, and Meghir (1998) estimator for the purpose of estimating earnings elasticities in the spirit of Gruber and Saez (2002) on the same sample. These results were, however, very unstable and are not further discussed here.

\footnotetext{
${ }^{30}$ For each country, we have also estimated specifications with household type dummies and education trends added; these alterations did not change the qualitative results except in the case of Norway, where the odd negative and significant elasticity disappears, and in the case of Sweden, where the elasticity becomes positive and significant.
} 


\begin{tabular}{|c|c|c|c|c|c|}
\hline \multirow{2}{*}{\multicolumn{2}{|c|}{ A. All }} & \multicolumn{2}{|c|}{ B. Men } & \multicolumn{2}{|c|}{ C. Women } \\
\hline & & & Australia & & Australia \\
\hline \multirow{2}{*}{ Financial gain from work } & $\begin{array}{l}\text { Australıa } \\
-0.110\end{array}$ & Financial gain from work & -0.098 & Financial gain from work & -0.002 \\
\hline & 0.091 & & 0.122 & & 0.174 \\
\hline \multirow[t]{2}{*}{$\mathrm{Nr}$ of cells } & 44 & $\mathrm{Nr}$ of cells & 23 & $\mathrm{Nr}$ of cells & 21 \\
\hline & Belgium & Fin ni 1 ar from u & Belgium & & Belgium \\
\hline \multirow[t]{2}{*}{ Financial gain from work } & 0.011 & Financial gain from work & $0.426^{* * *}$ & Financial gain from work & 0.002 \\
\hline & 0.146 & $\mathrm{Nr}$ of cells & 0.164 & & 0.041 \\
\hline \multirow[t]{2}{*}{$\mathrm{Nr}$ of cells } & 44 & Nr of cells & 24 & $\mathrm{Nr}$ of cells & 20 \\
\hline & Canada & & Canada & & Canada \\
\hline \multirow[t]{2}{*}{ Financial gain from work } & 0.021 & Financial gain from work & 0.013 & Financial gain from work & $0.105^{*}$ \\
\hline & 0.018 & $\mathrm{Nr}$ of cells & $\begin{array}{c}0.022 \\
96\end{array}$ & $\mathrm{Nr}$ of cells & $\begin{array}{c}0.063 \\
93\end{array}$ \\
\hline $\mathrm{Nr}$ of cells & $\begin{array}{c}189 \\
\text { Czech Republic }\end{array}$ & & Czech Republic & & Czech Republic \\
\hline \multirow[t]{2}{*}{ Financial gain from work } & 0.013 & Financial gain from work & $0.199 * *$ & Financial gain from work & -0.042 \\
\hline & 0.115 & $\mathrm{Nr}$ of cells & $\begin{array}{c}0.099 \\
24\end{array}$ & $\mathrm{Nr}$ of cells & $\begin{array}{c}0.218 \\
23\end{array}$ \\
\hline \multirow{2}{*}{$\mathrm{Nr}$ of cells } & 47 & & Denmark & & Denmark \\
\hline & $\begin{array}{l}\text { Denmark } \\
0121 *\end{array}$ & Financial gain from work & $0.100 * *$ & Financial gain from work & 0.161 \\
\hline Financial gain from work & $\begin{array}{c}0.121^{*} \\
0.062\end{array}$ & & 0.041 & & 0.120 \\
\hline \multirow[t]{2}{*}{$\mathrm{Nr}$ of cells } & 120 & $\mathrm{Nr}$ of cells & 60 & $\mathrm{Nr}$ of cells & 60 \\
\hline & Finland & & Finland & & Finland \\
\hline \multirow[t]{2}{*}{ Financial gain from work } & $0.171 * * *$ & Financial gain from work & $0.173^{*}$ & Financial gain from work & $0.163^{* *}$ \\
\hline & 0.062 & $\mathrm{Nr}$ of cells & $\begin{array}{c}0.101 \\
60\end{array}$ & $\mathrm{Nr}$ of cells & $\begin{array}{c}0.072 \\
60\end{array}$ \\
\hline $\mathrm{Nr}$ of cells & $\begin{array}{l}120 \\
\text { Germany }\end{array}$ & 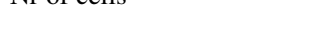 & Germany & (1) & Germany \\
\hline \multirow{2}{*}{ Financial gain from work } & $\begin{array}{l}\text { Germany } \\
-0.106\end{array}$ & Financial gain from work & $0.092 *$ & Financial gain from work & 0.074 \\
\hline & 0.085 & & 0.053 & & 0.130 \\
\hline $\mathrm{Nr}$ of cells & 117 & $\mathrm{Nr}$ of cells & Jsrael 60 & $\mathrm{Nr}$ of cells & 57 \\
\hline \multirow[t]{2}{*}{ Financial gain from work } & $\begin{array}{l}\text { Israel } \\
\quad 0.165 * * *\end{array}$ & Financial gain from work & $\begin{array}{c}\text { Israel } \\
0.134 * * \\
0.059\end{array}$ & Financial gain from work & $\begin{array}{l}\text { Israel } \\
\quad 0.174 * * *\end{array}$ \\
\hline & $\begin{array}{c}0.039 \\
96\end{array}$ & $\mathrm{Nr}$ of cells & $\begin{array}{c}0.059 \\
48\end{array}$ & $\mathrm{Nr}$ of cells & $\begin{array}{c}0.049 \\
48\end{array}$ \\
\hline $\mathrm{Nr}$ of cells & Norway & & Norway & & Norway \\
\hline \multirow[t]{2}{*}{ Financial gain from work } & $-0.044^{*}$ & Financial gain from work & -0.072 & Financial gain from work & -0.035 \\
\hline & 0.027 & $\mathrm{Nr}$ of cells & $\begin{array}{c}0.059 \\
60.000\end{array}$ & $\mathrm{Nr}$ of cells & $\begin{array}{c}0.032 \\
60\end{array}$ \\
\hline $\mathrm{Nr}$ of cells & 120 & NI OI Cetis & Netherlands & Nit or cetis & Netherlands \\
\hline \multirow{3}{*}{ Financial gain from work } & Netherlands & Financial gain from work & $0.193 *$ & Financial gain from work & 0.233 \\
\hline & $\begin{array}{c}-0.06 / \\
0.148\end{array}$ & & 0.101 & & 0.297 \\
\hline & $\begin{array}{c}0.140 \\
63\end{array}$ & $\mathrm{Nr}$ of cells & 33 & $\mathrm{Nr}$ of cells & 30 \\
\hline $\mathrm{Nr}$ of cells & Sweden & & Sweden & & Sweden \\
\hline Financial gain from work & 0.011 & Financial gain from work & 0.039 & Financial gain from work & -0.007 \\
\hline & 0.052 & Nrof collo & 0.056 & Nrof colls & 0.083 \\
\hline $\mathrm{Nr}$ of cells & 96 & NI or cells & $\begin{array}{c}48 \\
\text { United Kingdom }\end{array}$ & Nr of cells & $\begin{array}{c}48 \\
\text { United Kingdom }\end{array}$ \\
\hline Financial gain from work & $\begin{array}{l}\text { United Kingdom } \\
-0.026\end{array}$ & Financial gain from work & -0.032 & Financial gain from work & 0.018 \\
\hline & 0.020 & Nrof $\mathrm{flll}_{\mathrm{c}}$ & 0.021 & $\mathrm{Nr} o f(\mathrm{cll} \mathrm{c}$ & 0.051 \\
\hline $\mathrm{Nr}$ of cells & 91 & Nror cells & $\begin{array}{c}40 \\
\text { United States }\end{array}$ & Nror cells & $\begin{array}{c}45 \\
\text { United States }\end{array}$ \\
\hline & United States & Financial gain from work & -0.010 & Financial gain from work & -0.124 \\
\hline Financial gain from work & $\begin{array}{r}-0.018 \\
0.016\end{array}$ & & 0.021 & & 0.122 \\
\hline $\mathrm{Nr}$ of cells & 168 & $\mathrm{Nr}$ of cells & 84 & $\mathrm{Nr}$ of cells & 84 \\
\hline
\end{tabular}

Note: Dependent variable: probability to have strictly positive earnings. All regressions contain cell dummies and year dummies. Cells are defined based on age, education and sex. Cells with less than 50 observations are excluded. The reported estimates are the elasticities of employment rate with respect to the difference in disposable income when working and when not working. Standard errors reported below the estimates are robust to heteroscedasticity. $*$ indicates significance at $10 \%$ level, $* * 5 \%$ level and $* * *$ at $1 \% \%$ level. 


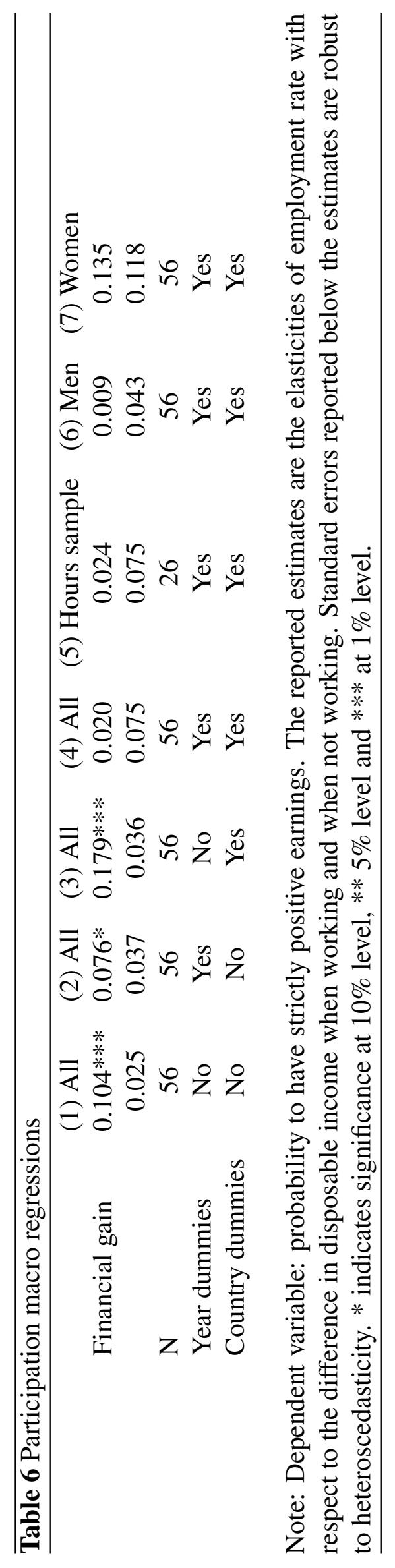




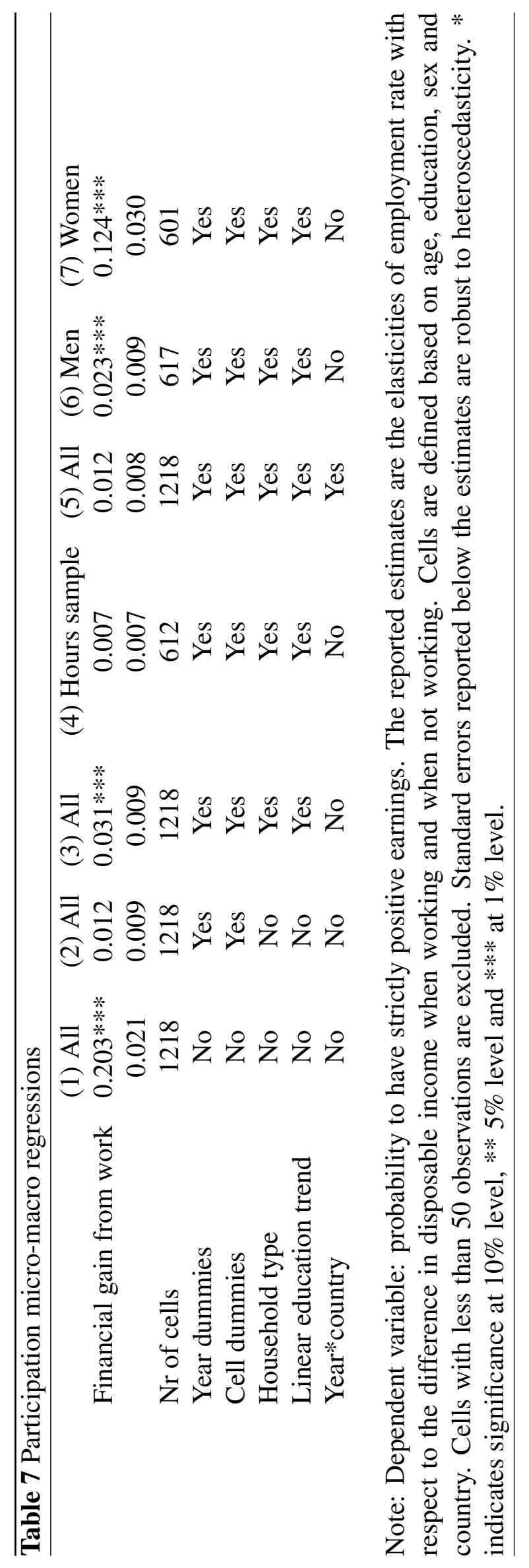




\subsection{Comparison to earlier macro studies}

Finally, we compare our macro-level results with typical specifications used earlier in macro studies on the impacts of taxes on aggregate working hours. The Prescott (2004) paper was based on simulations, not on regression analysis. However, Chetty et al. (2011b) use his data and regress log aggregate hours on $\log$ (1-tax rate) and get an elasticity of 0.7. Other macro studies, such as Davies and Henrekson (2004) and Alesina, Glaeser, and Sacerdote (2005), typically proceed as follows: They regress aggregated total hours, divided by population aged 15-64, on a tax wedge variable, with or without including country fixed effects. Some studies also include control variables, such as unionisation. The tax wedge variable takes into account not only income taxes, but also social security contributions paid by the employers and the employees, and consumption taxes. Note that the tax variable is typically based on average tax rates, although Prescott multiplies income taxes by a factor of 1.6 (which is the ratio of marginal taxes to average taxes in the US).

We follow the same approach and run similar regressions for the same countries included in our macro data. We present models both with and without country and year fixed effects. The source for the country-level data is McDaniel (2012). The number of observations is somewhat smaller in the comparision analysis. The reason is that the observations for Israel are missing in the aggregate macro-level tax data.

When examining the correlation between the average tax rate in the McDaniel data and the country mean statutory marginal tax rate, calculated by us, it turns out that the correlation is around 0.7 . The correlation between the macro average tax rate and our measure of the effective marginal tax rate is actually larger at 0.8 .

Macro-level estimates of the elasticity of aggregate working hours with respect to net of tax rate of the macro tax wedge, presented in Table 8, indicate that the elasticity is positive and significant without country and year fixed effects in both the total sample (0.22) and in the hours sample (0.26). However, the coefficient for the net-of-tax wedge loses significance when country and time dummies are added to the regression equation.

\section{Conclusions}

Much of the microeconometric evidence on the impacts of taxes on labour supply builds on reliable identification in principle, but the tax variation is often quite limited and the comparison groups can also be affected by tax changes via general equilibrium effects. In the macro work, by contrast, identification is blurred by other confounding factors (taxation is only one possible reason why the aggregate hours differ), but on the other hand, cross-country tax differences are greater and they can have a potential for estimating long-term steady-state differences in working hours across countries.

This paper attempts to build bridges between these two polar approaches by estimating, using the same micro data from many countries, micro, macro and intermediate (micro-macro) estimates of 
Table 8 Macro regressions with average tax rates

Total sample Total sample Hours sample Hours sample

$\begin{array}{lcccc}\text { Net of tax wedge } & 0.221 * * * & 0.681 & 0.263 * * & 0.914 \\ & 0.064 & 0.551 & 0.124 & 1.011 \\ \text { Year dummies } & \text { No } & \text { Yes } & \text { No } & \text { Yes } \\ \text { Country dummies } & \text { No } & \text { Yes } & \text { No } & \text { Yes } \\ \text { N } & 52 & 52 & 26 & 26\end{array}$

Note: The dependent variable in the first two columns is working hours per adult population. The reported estimates are elasticities with respect to 1-average tax wedge, where tax wedge is equal to 1(labour income tax rate)/[(1+consumption tax rate)*(1+payroll tax rate)]. Robust standard errors used. Both the dependent and independent variables are from McDaniel (2012). * indicates significance at $10 \%$ level, ** 5\% level and *** at $1 \%$ level.

labour supply, including both the intensive and extensive margins. The main aim is to examine if it is indeed the case that the macro-level estimates of labour supply are greater than micro estimates, as interesting and somewhat provocative recent research has suggested. In our macro-level analysis, the variables are aggregated from the theoretically correct micro concepts, and we thus use effective marginal tax rates, virtual incomes and participation tax rates both at the micro and the macro level. To our knowledge, our paper is the first analysis of differences in micro- and macro-level elasticities using cross-country individual data.

We believe that examining cross-country micro data is of crucial importance; at the same time, there are also caveats in the approach. For example, the tax and benefit modelling is necessarily more crude than in a single-country study, leading to possible measurement errors. While we have examined the robustness of many of the results, there is clearly a need to interpret the exact magnitude of the results cautiously.

With these caveats in mind, it can be said that the results do not provide clear support for the view that macro estimates would be higher than micro estimates. Our macro-level estimates are close to micro estimates; the hours estimate at the macro level is somewhat higher than the corresponding micro one, but this finding is based on a more limited number of country-level observations than one would hope for.

The upper limit of the confidence interval of both participation and hour elasticities are below one, suggesting that very high macro estimates, of the order of 1 to 2, are unlikely. Note that our estimates capture important life cycle aspects (retirement margin) and at least some part of dynamic learning by doing elements (when we estimate models at the macro level without country dummies); both of these effects have been suggested as possible reasons why macro estimates could be sizeable. For the Nordic countries, the results suggest that maintaining high tax rates does not necessarily rule out high employment rates, provided that other relevant policies are well designed. 


\section{Appendix A: Budget constraints and marginal effects}

The following details how we estimate the budget constraint for an individual taxpayer. Once the budget constraint has been calculated we can compute the marginal tax rate (the first derivative of the tax function locally where the taxpayer is located) and the virtual income (defined in the empirical section).

We use the individual as the unit of analysis. Given that we have data on individual level earnings, we will be able to calculate budget constraints in the consumption-earnings space. This is in line with the long micro-econometric tradition in labour supply estimation that studies individuals' supply of work hours given information on the individuals' budget constraints. We also adopt the somewhat strong assumption that the individual takes the other spouse's earnings as given. ${ }^{31}$

The following notation will be used. For any income variable we define

$$
x_{H}=x_{j}+x_{-j}
$$

where subscript $H$ denotes total household income, $j$ is an individual index and $-j$ denotes the spouse of individual $j$.

$z_{j}=$ earned income

$B_{j}=$ capital income

$q_{j}=z_{-j}+B_{j}+B_{-j}=$ other gross household income

$g(x)=\operatorname{taxes}($ transfers not included)

$\operatorname{tr}(x)=$ transfers

$T^{H}(x)=g(x)-\operatorname{tr}(x)=$ tax function for the family, including both taxes paid and transfers received.

The structure of $g$ differs depending on whether the tax system is joint/separate with respect to family income. It also differs depending on whether or not labour income and capital income are taxed on the same schedule (global/comprehensive income tax) or using a separate schedule (dual income tax).In many OECD countries, transfer systems, captured by $t r$, are functions of family income.

1. Joint taxation of spouses + global income tax

$$
T^{H}=g-t r=g\left(z_{H}+B_{H}\right)-\operatorname{tr}\left(z_{H}+B_{H}\right)
$$

\footnotetext{
${ }^{31}$ In a statistical sense, this is not necessarily a strong assumption in our analysis as we will instrument for virtual incomes with the same type of instruments that we use to instrument for the marginal tax rate. The rank condition is then probably more critical (see the discussion in Blundell, Duncan, and Meghir, 1998).
} 
2. Separate taxation of spouses + global income $\operatorname{tax}^{32}$

$$
T^{H}=g-t r=g_{j}\left(z_{j}+B_{j}\right)+g_{-j}\left(z_{-j}+B_{-j}\right)-\operatorname{tr}\left(z_{H}+B_{H}\right)
$$

3. Separate taxation of spouses + dual income tax

$$
T^{H}=g-t r=g_{j}\left(z_{j}\right)+g_{-j}\left(z_{-j}\right)+\tau_{c}\left(B_{j}+B_{-j}\right)-\operatorname{tr}\left(z_{H}+B_{H}\right)
$$

In what follows, we are interested in the budget constraint in the $C, z-$ plane, while taking capital income and spousal income as given.

1. Joint taxation of spouses + global income tax

In $1, T^{H}$ is a function of family income $z_{H}+B_{H}$. One can then simply estimate $T^{H}$ as a function of $z_{H}+B_{H}$ for those countries. Equipped with an estimate of the tax function, we can compute marginal tax rates and virtual income in the following way. Following the notation in the empirical section we let non-labour income be given by

$$
m=\hat{q}-T^{H}(\hat{q})
$$

where the hat indicates that these variables are exogenously given. Consumption is given by

$$
C=z_{j}-\left[T^{H}\left(z_{j}+\hat{q}_{j}\right)-T^{H}\left(\hat{q}_{j}\right)\right]+m=z_{j}-T\left(z_{j} \mid \hat{z}_{-j}, \hat{B}_{j}, \hat{B}_{-j}\right)+m .
$$

We are now back in the notation from the empirical section. The tax on labour income $T\left(z_{j} \mid \hat{z}_{-j}, \hat{B}_{j}, \hat{B}_{-j}\right)$ now depends on spousal income and capital income. The derivative we are interested in (the slope of the budget constraint) is

$$
\frac{d C}{d z_{j}}=1-\frac{\partial T}{\partial z_{j}}=1-\frac{\partial T^{H}}{\partial z_{j}}=1-\tau .
$$

Virtual income for each individual can now be calculated as

$$
R=m+\tau z_{j}-T\left(z_{j}\right)=m+\tau z_{j}-\left[T^{H}\left(z_{j}\right)-T^{H}(0)\right]=\hat{q}_{j}+\tau z_{j}-T^{H}\left(z_{j}+\hat{q}_{j}\right)
$$

Note that all variables in equation 17 , except for $\tau$, are directly observed in the data. Once we have estimated the slope term we can obtain a measure of virtual income. Equation 17 also generalises to system 2 and 3 . The challenge is to get the slope right.

\footnotetext{
${ }^{32}$ Another possibility is that earned income is taxed separately and capital income is taxed jointly. This was indeed the case in Sweden 1971-1986.
} 
2. Separate taxation of spouses + global income tax

When there is separate taxation of spouses most transfers systems are functions of total household income whereas statutory taxes are functions of individual level earned income and capital income. One way to deal with this would be to estimate one function for transfers (possibly for different number of kids in the household) and a separate function for individual level earnings. Thus, we would like to separately estimate $g_{j}\left(z_{j}+B_{j}\right)$ and $\operatorname{tr}\left(z_{H}+B_{H}\right)$. Actually, in the paper we do not estimate the derivative of $g_{j}$, but we use external information of tax schedules as described in Section 3.2. However, we estimate the derivative of $t r$ directly in the data. Consumption is given by

$$
\begin{aligned}
C & =z_{j}-\left[T^{H}\left(z_{j}+B_{j}, \hat{z}_{-j}+\hat{B}_{-j}\right)-T^{H}\left(0+B_{j}, \hat{z}_{-j}+\hat{B}_{-j}\right)\right]+m \\
& =z_{j}-T\left(z_{j} \mid \hat{z}_{-j}, \hat{B}_{j}, \hat{B}_{-j}\right)+m \\
& =z_{j}-T^{H}\left(z_{j}+B_{j}, \hat{z}_{-j}+\hat{B}_{-j}\right)+\hat{q}_{j} \\
& =z_{j}-g_{j}\left(z_{j}+\hat{B}_{j}\right)-g_{-j}\left(z_{-j}+\hat{B}_{-j}\right)+\operatorname{tr}\left(z_{j}+\hat{q}_{j}\right)+\hat{q}_{j} .
\end{aligned}
$$

The slope we are interested in is

$$
\frac{d C}{d z_{j}}=1-\frac{\partial T}{\partial z_{j}}=1-\frac{\partial T^{H}}{\partial z_{j}}=1-\frac{\partial g_{j}\left(z_{j}+B_{j}\right)}{\partial z_{j}}+\frac{\partial \operatorname{tr}\left(z_{j}+z_{-j}+B_{j}+B_{-j}\right)}{\partial z_{j}}=1-\tau
$$

This underlines that we need to estimate both $g_{j}\left(z_{j}+\hat{B}_{j}\right)$ and $\operatorname{tr}\left(z_{H}+B_{H}\right)$.

Virtual income can now be written as

$$
\begin{aligned}
R & =m+\tau z_{j}-T\left(z_{j}\right) \\
& =m+\tau z_{j}-\left[T^{H}\left(z_{j}\right)-T^{H}(0)\right]=\hat{q}_{j}+\tau z_{j}-T^{H}\left(z_{j}+\hat{q}_{j}\right) \\
& =\hat{q}_{j}+\tau z_{j}-g_{j}\left(z_{j}+B_{j}\right)-g_{-j}\left(z_{-j}+B_{-j}+\operatorname{tr}\left(z_{j}+\hat{q}_{j}\right),\right.
\end{aligned}
$$

where, once again, only the marginal tax rate $\tau$ needs to be estimated. Everything else is observed in the data. To obtain the first derivative we estimate the tax function $g_{j}\left(z_{j}+B_{j}\right)$ as a function of $z_{j}+B_{j}$

3. Separate taxation of spouses + dual income tax Consumption can now be written as

$$
\begin{aligned}
C & =z_{j}-\left[T^{H}\left(z_{j}, \hat{B}_{j}, \hat{z}_{-j}, \hat{B}_{-j}\right)-T^{H}\left(0, \hat{B}_{j}, \hat{z}_{-j}, \hat{B}_{-j}\right)\right]+m \\
& =z_{j}-T\left(z_{j} \mid \hat{z}_{-j}, \hat{B}_{j}, \hat{B}_{-j}\right)+m \\
& =z_{j}-T^{H}\left(z_{j}, \hat{B}_{j}, \hat{z}_{-j}+\hat{B}_{-j}\right)+\hat{q}_{j} \\
& =z_{j}-g_{j}\left(z_{j}\right)-g_{-j}\left(z_{-j}\right)-\tau_{c}\left(\hat{B}_{j}+\hat{B}_{-j}\right)+\operatorname{tr}\left(z_{j}+\hat{q}_{j}\right)+\hat{q}_{j} .
\end{aligned}
$$


The key thing now is that the tax function must be estimated as a function of earned income only. Otherwise the estimated marginal tax rate will be wrong in many cases.

\section{Appendix B: The extensive margin}

The theoretical notion underlying our extensive margin model is that individuals make a choice between two consumption-leisure bundles. If the individual choose to work she consumes $C_{w}$ dollar and earns $\hat{z}$ dollar. If she chooses not to work she consumes $C_{n w}$ and earns 0 dollar. While retaining the notation from appendix A we write consumption in the state of work, $C_{i h c t, w}$ for an individual of household type $h$ in country $c$ in time period $t$ in the following way

$$
C_{i h c t, w}=\hat{z}_{i t}+z_{-i t}+B_{i t}+B_{-i t}-T^{h c t}\left(\hat{z}_{i t}, z_{-i t}, B_{i t}, B_{-i t}\right)
$$

where $T^{h c t}$ is the tax function for household type $h$ in country $c$ at time $t$. The analogue for consumption in the state of non-work is

$$
C_{i h c t, n w}=0+z_{-i t}+B_{i t}+B_{-i t}-T^{h c t}\left(0, z_{-i t}, B_{i t}, B_{-i t}\right) .
$$

Ultimately, we are interested in the difference in disposable income between the two states:

$$
C_{i h c t, w}-C_{i h c t, n w}=\hat{z}_{i t}-\left[T^{h c t}\left(\hat{z}_{i t}, z_{-i t}, B_{i t}, B_{-i t}\right)-T^{h c t}\left(0, z_{-i t}, B_{i t}, B_{-i t}\right)\right] .
$$

To obtain an estimate of $C_{i h c t, w}-C_{i h c t, n w}$ we proceed using a simple and transparent approach utilising cell means. For single households (with or without children) we use the cell means $\overline{T^{c t}\left(z_{i t}, B_{i t}, B_{-i t}\right)}$ and $\overline{T^{c t}\left(0, B_{i t}, B_{-i t}\right)}$ to get estimates for the net taxes (i.e. taxes-transfers) in the states of work and no work, respectively. Cells are, as in the regression analysis, constructed using sex, education, household type and age. Likewise, the cell mean labour income $\overline{z_{i t}}$ for those whose earnings are strictly positive is used to get an estimate of the expected income for the individual when working.

For couples (again with or without children), we concentrate on comparing cases where both spouses work with those with only one working spouse, which we think is the most relevant case. Then the cell means are $\overline{T^{c t}\left(\hat{z}_{i t}, z_{-i t}, B_{i t}, B_{-i t}\right)}$ (where the earnings for both adults are strictly positive) and $\overline{T^{c t}\left(0, z_{-i t}, B_{i t}, B_{-i t}\right)}$ (where the earnings of one spouse are strictly positive and the earnings for the other spouse are zero), and these are used to estimate net taxes in the states of work and no work, respectively. To get an estimate of individual level expected labour income, we take the cell average earnings for both couples when they both work and divide it by two, i.e. $\overline{\left(z_{i t}+z_{-i t}\right)} / 2$. 


\section{References}

Alesina, Alberto, Edward Glaeser, and Bruce Sacerdote (2005). "Work and Leisure in the United States and Europe: Why So Different?" In: NBER Macroeconomics Annual 20, pp. 1-64.

Angrist, Joshua D and Jörn-Steffen Pischke (2008). Mostly Harmless Econometrics: An Empiricist's Companion. Princeton University Press.

Bargain, Olivier, Kristian Orsini, and Andreas Peichl (2014). "Comparing Labor Supply Elasticities in Europe and the U.S.” In: Journal of Human Resources. Forthcoming.

Blomquist, Sören, Vidar Christiansen, and Luca Micheletto (2010). "Public provision of private goods and nondistortionary marginal tax rates". In: American Economic Journal: Economic Policy 2, pp. 1-27.

Blundell, R, A Duncan, and C Meghir (1998). "Estimating labor supply responses using tax reforms". In: Econometrica 66, pp. 827-861.

Blundell, Richard, Antoine Bozio, and Guy Laroque (2011). Extensive and intensive margins of labour supply: working hours in the US, UK and France. IFS Working Paper 01/11. IFS.

Chetty, Raj (2012). "Bounds on elasticities with optimization frictions: a synthesis of micro and macro evidence on labor supply". In: Econometrica 80.3, pp. 968-1018.

Chetty, Raj, John Friedman, Tore Olsen, and Luigi Pistaferri (2011a). "Adjustment Costs, Firm Responses, and Micro vs. Macro Labor Supply Elasticities: Evidence from Danish Tax Records”. In: Quarterly Journal of Economics 126.2, pp. 749-804.

Chetty, Raj, Day Manoli, Adam Guren, and Andrea Weber (2011b). “Are Micro and Macro Labor Supply Elasticities Consistent? A Review of Evidence on the Intensive and Extensive Margins”. In: American Economic Review Papers and Proceedings 101, pp. 471-75.

- (2012). "Does Indivisible Labor Explain the Difference between Micro and Macro Elasticities? A Meta-Analysis of Extensive Margin Elasticities”. In: NBER Macroeconomics Annual. Forthcoming in 2012.

Davies, Steven J. and Magnus Henrekson (2004). Tax effects on work activity, industry mix and shadow economy size: evidence from rich-country comparisons. Tech. rep. SSE/EFI Working Paper Series in Economics and Finance.

Gruber, Jon and Emmanuel Saez (2002). “The Elasticity Of Taxable Income: Evidence And Implications". In: Journal of Public Economics 84, pp. 1-32.

Imai, Susumu and Michael P Keane (2004). "Intertemporal Labor Supply and Human Capital Accumulation". In: International Economic Review 45, pp. 601-642.

Immervoll, Herwig, Henrik Kleven, Claus Thustrup Kreiner, and Emmanuel Saez (2007). "Welfare Reform in European Countries: A Microsimulation Analysis”. In: Economic Journal 117, pp. 144.

Keane, Michael P and Richard Rogerson (2012). "Micro and Macro Labor Supply Elasticities: A Reassessment of the Conventional Wisdom”. In: Journal of Economic Literature 50.2, pp. 564-576. 
Lindbeck, Assar, Sten Nyberg, and Jörgen Weibull (1999). "Social Norms and Economic Incentives in the Welfare State". In: Quarterly Journal of Economics 114, pp. 1-35.

Ljungqvist, Lars, Thomas J Sargent, Olivier Blanchard, and Edward C Prescott (2006). "Do Taxes Explain European Employment? Indivisible Labor, Human Capital, Lotteries, and Savings [with Comments and Discussion]". In: NBER Macroeconomics Annual 21, pp. 181-246.

Loader, Clive (1999). Local Regression and Likelihood. Statistics and Computing. New York: SpringerVerlag.

Luxembourg Income Study Database (LIS) (2014). http: / / www. I isdatacenter. org (multiple countries; microdata last accessed in July 2014). Statistical micro-level database. Luxembourg: LIS.

McDaniel, Cara (2012). Average tax rates on consumption, investment, labor, and capital in the OECD 1950-2003. Mimeo. Arizona State University.

Meghir, Costas and David Phillips (2010). "Labour supply and taxes”. In: Dimensions of Tax Design: the Mirrlees Review. Ed. by James Mirrlees, S Adam, Timothy Besley, Richard Blundell, S Bond, R Chote, M Gammie, P Johnson, G Myles, and James Poterba. Oxford University Press.

Nickell, Stephen (2003). Employment and Taxes. CESifo Working Paper 1109. CESifo.

Oh, Seung-Yun, Yongjin Park, and Samuel Bowles (2012). "Veblen effects, political representation, and the reduction in working time over the 20th century". In: Journal of Economic Behavior and Organization. Forthcoming.

Ohanian, Lee, Andrea Raffo, and Richard Rogerson (2008). "Long-term changes in labor supply and taxes: Evidence from OECD countries". In: Journal of Monetary Economics 55.8, pp. 1353-1362.

Piketty, Thomas, Emmanual Saez, and Stefanie Stantcheva (2011). Optimal taxation of top labor incomes: a tale of three elasticities. Working Paper 17616. NBER.

Pirttilä, Jukka and Håkan Selin (2011). Tax policy and employment: How does the Swedish system fare? Working Paper 2. Uppsala Center for Fiscal Studies.

Prescott, Edward C (2002). "Prosperity and Depression". In: The American Economic Review 92.2, pp. $1-15$.

- (2004). "Why do Americans work so much more than the Europeans". In: Federal Reserve Bank of Minneapolis Quarterly Review 28.1, pp. 2-13.

Rogerson, Richard (2007). Taxation and Market Work: Is Scandinavia an Outlier? Working Paper 12890. National Bureau of Economic Research.

Rogerson, Richard and Johanna Wallenius (2009). "Micro and Macro Elasticities in a Life Cycle Model with Taxes". In: Journal of Economic Theory 1448, pp. 2277-2292.

Saez, Emmanuel, Joel Slemrod, and Seth Giertz (2012). "The Elasticity of Taxable Income with Respect to Marginal Tax Rates: A Critical Review". In: Journal of Economic Literature 50.1, pp. 350. 